\title{
SUBJECTIVE VERSUS DIGITAL IMAGE ANALYSIS OF THE CORNEAL OPACITY AS A TOOL FOR ESTIMATION OF TIME SINCE DEATH WITH STUDYING THE EFFECTS OF EYE CLOSURE AND AMBIENT TEMPERATURE
}

\author{
Melad G. Paulis**, Rehab H. A. Younis* \\ *Forensic Medicine and Clinical Toxicology Department, Faculty of Medicine, Minia \\ University, Egypt. \\ ${ }^{\#}$ Internal Medicine Department, Faculty of Medicine, Mutah University, Jordan. \\ Corresponding author: Rehab H A Younis Email: hosni.rehab@yahoo.com
}

\begin{abstract}
Estimation of time pass since death is a great forensic confrontation. Corneal opacity is an endorsed forensic tool for estimation of time pass since death. Previous researches depend on subjective way while others used digital image analysis system. In this study we compare subjective and digital image analysis methods, in addition to studying effect of eye closure and temperature on development of corneal opacity. Closed and opened rabbit eyes corneas were photographed at different postmortem intervals. A scoring system was used to assess the cornea opacity. Image analysis was done by MATLAB software. Simple regression analysis revealed better prediction of the postmortem intervals using image analysis parameters than when subjective assessment was employed. On using multiple regression analysis, there is improvement of SEE from 2.5-3.6 hr. to 1.1-1.3 when using equation of 3 elements of colors red, green and blue. Corneal opacity slightly increased in closed eye than in opened one. In summer corneal opacity occur faster than in winter.
\end{abstract}

Key words: time pass since death, corneal opacity, digital imaging, eye closure, temperature 


\section{INTRODUCTION}

Estimation of time since death continues to be a major forensic challenge. Physical and anatomical changes can be used for its estimation and to obtain more precise results, forensic pathologists should use more than one method, taking in consideration the influence of environment (Henssge and Madea, 2004).

Cornea is a transparent avascular tissue which composed of water $(78 \%)$, collagen $(15 \%)$, other protein $(5 \%)$, ground substance $(1 \%)$ and salts (1\%). A lot of factors are contributed to corneal transparency, such as lamellar arrangement of collagen bundles in corneal stroma, regular and uniform arrangement of corneal epithelium, intercellular junctions, relative controlled hydration of normal cornea and corneal avascularity (Bowling, 2015).

Numerous corneal parameters have been studied as a tool for estimation of time since death. However, many investigations involved corneal removal. For example corneal structure changes (Fang et al., 2007), corneal thickness (Meng et al., 2001), corneal histology (Song and Shi, 2001, Chen et al., 2007), and DNA corneal changes (Liu and Xiong, 2003). However، corneal removal causes facial disfigurement, so it is not favorable.

Digitalization invades every part of our live and forensic science is not away from rapidly advanced computer technology. Image processing or analysis has been widely used in many forensic areas from fingerprint examination to DNA analysis (Zbieć-Piekarska et al., 2015, Dubey et al., 2016).

Aoki (Aoki, 1965) noticed that corneal opacity increased with time passed since death using a subjective method. Meanwhile, corneal opacity changes after death become an interesting research topic; some publications discussed factors affecting corneal opacity using examiner judgment (Tsunenari et al., 1977, Kumar et al., 2012). Other researchers tried to introduce different objective methods to increase accuracy of results such as grey scale method (Furukawa et al., 1985), laser light transmission measurement (Tsunenari et al., 1971, Tsunenari et al., 1974).

Zhou et al., (Zhou et al., 2010) used a computer image analysis technology for quantification of corneal opacity; however they mentioned one limitation of their study as they neither examine effect of eye closure, nor put in consideration the ambient temperature. Here in the present study, a comparison between subjective examination and digital image analysis of the corneal opacity as tools in estimating postmortem interval. In addition, authors studied the effects of eye closure and temperature on the rate of development of corneal opacity. 


\section{MATERIALS \& METHODS}

Adult rabbits were obtained from Faculty of Veterinary, Minia University. All procedures and animal handling were done in accordance with recommendations of ethical committee of Faculty of Medicine, Minia University. Rabbits were left for 1 week in the same experimental conditions for accommodation. Rabbits were divided into the following groups (10 rabbits each): at death; 6, 12 , 18, 24, 30, 36, 42, 48, 54, $60 \mathrm{hr}$. after death. After rabbit's scarification (by cervical decapitation under general anesthesia), left eye was kept opened by hemostatic forceps while the right eye was closed till the time of imaging. After death, rabbits were left at the room temperature. The experiment was done twice; one in the summer with hot

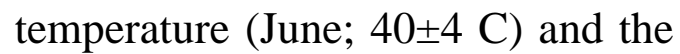
second in winter (January; 15 $\pm 3 \mathrm{C}$ ).

Image recording

$\begin{array}{ccr}\text { Rabbit's } & \text { eyes } & \text { were } \\ \text { photographed } & \text { using } & \text { Canon }\end{array}$
PowerShot SX60 HS camera (Canon, USA). A fixed desk light was used as the only source of light during photographing. The camera was fixed approximately $15 \mathrm{~cm}$ away from the rabbit eye. The light source was to the right to rabbit.

Subjective study

A scoring system was used to assess the cornea opacity. A score 1, 2, 3, and 4 for no, slight, moderate, and severe corneal opacity respectively (figure 1) (Salam et al., 2012). For each examined time, a score was given. One observer examined rabbit eyes throughout the study.

\section{Image processing}

A digital image is a picture that has been changed to a computer understandable binary arrangement consisting of logical 0s and 1s. It is a representation of a physical image as a set of numbers that can be readable by a computer. The digital image is divided into small squares called pixels which stand for picture elements. For each pixel, the imaging device records a number, or a small set of numbers, that describe some property of this pixel, such as its brightness (the intensity of the light) or its color. The numbers are organized in an array of rows and columns that correspond to the vertical and horizontal positions of the pixels in the image. Digital images have several basic features(Viner, 2018, Yang et al., 2017).

As the iris has different colors, the area selected for image analysis was that of the cornea opposite the pupil. Four points were selected over the pupil area of the cornea (figure 2). For the color images red, green and blue pixel values were recorded, and the mean value of the 4 selected points was calculated for each examined color.

Image analysis was done by MATLAB software (version R2016b, 64-bit, MathWorks, USA). This software enables authors to detect pixel value for each examined color (figure 3 ). 


\section{Statistical analysis}

Statistical analysis of data was conducted using SPSS 24 for windows (SPSS, Chicago, USA). Data were tested for difference using repeated measures ANOVA and post hoc test and least significant difference (LSD) and Chi-square for non-parametric data. Simple and multiple regression analysis were done to generate equations for estimation of PMI from different examined variable. Statistically significant differences were determined at $\mathrm{P}<0.05$. Data were expressed as mean $\pm \mathrm{SD}$.

\section{RESULTS}

Table 1 and 2 depict the results of subjective assessment of corneal opacity of rabbit eyes in winter and summer time respectively. There is a gradual increase in the corneal opacity over time. There is slight increase in the corneal opacity in the closed eye in comparing with opened one. This is true for summer and winter times.

Examining corneal images with MATLAB showed decreased all R, $\mathrm{G}$, and $\mathrm{B}$ pixel values over time (table 3). There are significant differences between different pixel values in different examined postmortem intervals. Figure 4, 5, and 6 illustrate more obviously the relation between pixel values of each color and the postmortem interval. In addition, these figures portrayed that there is more decrease in all pixel values in closed eyes in the same ambient temperate than opened eyes. And there is more decrease in the pixel values in summer than winter times.

Table (4) shows the correlation coefficients between postmortem interval and the examined different parameters. There are strong correlation coefficients between image analysis results that that of subjective assessment of corneal images. In addition, red pixel values give the strongest correlation with postmortem interval $(\mathrm{r}=0.78-0.83)$. Subjective assessment of the corneal images gives moderate correlation with postmortem intervals $(r=0.46-0.53)$.

For the prediction of postmortem interval from subjective and image analysis parameters; simple regression analysis was used. Table 5 and 6 show the developed equations. There is better prediction of the postmortem intervals using image analysis parameters than when subjective assessment was employed. This appeared from the improved SEE of image analysis than that of subjective assessment.

On using multiple regression analysis, there is slight improvement in the prediction of postmortem interval. SEE decreased from 2.5-3.6 hr. when individual colors were used in the equation to 1.1-1.3 when the 3 elements of colors (R, G, and B) were used (table 7). 
Table (1): Subjective assessment of the corneal opacity of 10 rabbit corneas examined at different postmortem intervals ( $\mathrm{hr}$. ) in winter time.

\begin{tabular}{|c|c|c|c|c|c|c|c|c|c|c|c|c|c|c|c|c|c|c|c|c|c|c|c|c|c|c|}
\hline & \multicolumn{2}{|c|}{ At death } & \multicolumn{2}{|l|}{6} & \multicolumn{2}{|c|}{12} & \multicolumn{2}{|c|}{18} & \multicolumn{2}{|l|}{24} & \multicolumn{2}{|c|}{30} & \multicolumn{2}{|l|}{36} & \multicolumn{2}{|c|}{42} & \multicolumn{2}{|c|}{48} & \multicolumn{2}{|c|}{54} & \multicolumn{2}{|l|}{60} & \multicolumn{2}{|l|}{66} & \multicolumn{2}{|l|}{72} \\
\hline & $C$ & 0 & C & 0 & C & 0 & C & 0 & C & 0 & $C$ & 0 & C & 0 & C & 0 & C & 0 & C & 0 & C & 0 & C & 0 & C & 0 \\
\hline $\begin{array}{l}\text { Score } \\
1\end{array}$ & 10 & 10 & 9 & 10 & 7 & 8 & & & & & & & & & & & & & & & & & & & & \\
\hline $\begin{array}{l}\text { Score } \\
2\end{array}$ & & & 1 & & 3 & 2 & 7 & 8 & 6 & 7 & 5 & 6 & 5 & 6 & 2 & 3 & 1 & 2 & & 1 & & & & & & \\
\hline $\begin{array}{l}\text { Score } \\
3\end{array}$ & & & & & & & 3 & 2 & 4 & 3 & 5 & 4 & 5 & 4 & 4 & 3 & 5 & 4 & 4 & 3 & 2 & 4 & 2 & 3 & & \\
\hline $\begin{array}{l}\text { Score } \\
4\end{array}$ & & & & & & & & & & & & & & & 5 & 4 & 4 & 4 & 6 & 6 & 8 & 6 & 8 & 7 & 10 & 10 \\
\hline
\end{tabular}

Data represent the numbers of rabbit corneas for each examined score in each time interval.

Score 1, 2, 3, and 4 for no, slight, moderate and, marked corneal opacity respectively. C: closed eye. O: opened eye.

Table (2): Subjective assessment of corneal opacity of 10 rabbit corneas examined at different postmortem intervals (hr.) in summer time.

\begin{tabular}{|c|c|c|c|c|c|c|c|c|c|c|c|c|c|c|c|c|c|c|c|c|c|c|c|c|c|c|}
\hline & \multicolumn{2}{|c|}{$\begin{array}{l}\text { At } \\
\text { death }\end{array}$} & \multicolumn{2}{|l|}{6} & \multicolumn{2}{|c|}{12} & \multicolumn{2}{|c|}{18} & \multicolumn{2}{|c|}{24} & \multicolumn{2}{|c|}{30} & \multicolumn{2}{|c|}{36} & \multicolumn{2}{|c|}{42} & \multicolumn{2}{|c|}{48} & \multicolumn{2}{|c|}{54} & \multicolumn{2}{|l|}{60} & \multicolumn{2}{|l|}{66} & \multicolumn{2}{|l|}{72} \\
\hline & $C$ & 0 & $C$ & 0 & $C$ & 0 & $C$ & 0 & $C$ & 0 & $C$ & 0 & $C$ & 0 & $C$ & 0 & $C$ & 0 & $C$ & 0 & $C$ & 0 & $C$ & 0 & $C$ & 0 \\
\hline $\begin{array}{l}\text { Score } \\
1\end{array}$ & 10 & 10 & 8 & 9 & 6 & 7 & & & & & & & & & & & & & & & & & & & & \\
\hline $\begin{array}{l}\text { Score } \\
2\end{array}$ & 0 & 0 & 2 & 1 & 4 & 3 & 6 & 5 & 4 & 4 & 2 & 3 & 1 & 2 & & & & & & & & & & & & \\
\hline $\begin{array}{l}\text { Score } \\
3\end{array}$ & & & & & & & 4 & 5 & 6 & 6 & 8 & 7 & 9 & 8 & 5 & 6 & 4 & 5 & 2 & 1 & & & & & & \\
\hline $\begin{array}{l}\text { Score } \\
4\end{array}$ & & & & & & & & & & & & & & & 5 & 4 & 6 & 5 & 8 & 9 & 10 & 10 & 10 & 10 & 10 & 10 \\
\hline
\end{tabular}

Data represent the numbers of rabbit corneas for each examined score in each time interval.

Score 1, 2, 3, and 4 for no, slight, moderate and, marked corneal opacity respectively. C:

closed eye. 0 : opened eye 
Table (3): Mean ( $\pm S D$ ) of pixel values of different colors of the corneas of rabbits' eye that examined in different postmortem periods and in different conditions.

\begin{tabular}{|c|c|c|c|c|c|c|c|c|c|c|c|c|}
\hline \multirow{3}{*}{$\begin{array}{l}\text { Postmortem } \\
\text { interval in } \\
\text { hr. }\end{array}$} & \multicolumn{6}{|c|}{ Summer time } & \multicolumn{6}{|c|}{ Winter time } \\
\hline & \multicolumn{3}{|c|}{ Closed eye } & \multicolumn{3}{|c|}{ Opened eye } & \multicolumn{3}{|c|}{ Closed eye } & \multicolumn{3}{|c|}{ Opened eye } \\
\hline & Red & Green & Blue & Red & Green & Blue & Red & Green & Blue & Red & Green & Blue \\
\hline At death & $120( \pm 5)$ & $116( \pm 6)$ & $98( \pm 7)$ & $125( \pm 5)$ & $118( \pm 6)$ & $95( \pm 5)$ & $121( \pm 7)$ & $111( \pm 5)$ & $99( \pm 4)$ & $120( \pm 5)$ & $118( \pm 6)$ & $101( \pm 4)$ \\
\hline 6 & $107( \pm 5)$ & $104( \pm 5)$ & $81( \pm 6)$ & $110( \pm 4)$ & $104( \pm 6)$ & $86( \pm 4)$ & $114( \pm 5)$ & $112( \pm 5)$ & $92( \pm 5)$ & $115( \pm 6)$ & $113( \pm 5)$ & $96( \pm 5)$ \\
\hline 12 & $97( \pm 4)$ & $97( \pm 5)$ & $69( \pm 6)$ & $100( \pm 6)$ & $98( \pm 6)$ & $77( \pm 3)$ & $100( \pm 7)$ & $99( \pm 4)$ & $78( \pm 5)$ & $105( \pm 7)$ & $103( \pm 5)$ & $86( \pm 5)$ \\
\hline 18 & $87( \pm 4)$ & $87( \pm 6)$ & $60( \pm 6)$ & $90( \pm 4)$ & $90( \pm 5)$ & $69( \pm 4)$ & $95( \pm 5)$ & $91( \pm 5)$ & $73( \pm 4)$ & $99( \pm 6)$ & $98( \pm 6)$ & $80( \pm 6)$ \\
\hline 24 & $73( \pm 4)$ & $73( \pm 4)$ & $51( \pm 5)$ & $77( \pm 5)$ & $75( \pm 6)$ & $54( \pm 3)$ & $80( \pm 5)$ & $82( \pm 5)$ & $58( \pm 4)$ & $87( \pm 6)$ & $88( \pm 5)$ & $68( \pm 6)$ \\
\hline 30 & $65( \pm 5)$ & $65( \pm 5)$ & $43( \pm 5)$ & $66( \pm 5)$ & $65( \pm 5)$ & $45( \pm 4)$ & $75( \pm 5)$ & $72( \pm 4)$ & $53( \pm 5)$ & $81( \pm 5)$ & $83( \pm 5)$ & $62( \pm 5)$ \\
\hline 36 & $55( \pm 6)$ & $55( \pm 4)$ & $33( \pm 4)$ & $60( \pm 5)$ & $57( \pm 4)$ & $44( \pm 4)$ & $66( \pm 4)$ & $65( \pm 4)$ & $44( \pm 5)$ & $76( \pm 5)$ & $77( \pm 5)$ & $57( \pm 5)$ \\
\hline 42 & $47( \pm 3)$ & $47( \pm 3)$ & $25( \pm 4)$ & $50( \pm 4)$ & $48( \pm 5)$ & $34( \pm 3)$ & $60( \pm 4)$ & $56( \pm 5)$ & $38( \pm 4)$ & $66( \pm 4)$ & $66( \pm 5)$ & $42( \pm 4)$ \\
\hline 48 & $41( \pm 4)$ & $41( \pm 4)$ & $19( \pm 4)$ & $45( \pm 3)$ & $42( \pm 4)$ & $30( \pm 3)$ & $53( \pm 3)$ & $50( \pm 5)$ & $31( \pm 3)$ & $58( \pm 5)$ & $59( \pm 5)$ & $38( \pm 5)$ \\
\hline 54 & $35( \pm 5)$ & $35( \pm 4)$ & $13( \pm 5)$ & $40( \pm 4)$ & $38( \pm 4)$ & $21( \pm 3)$ & $45( \pm 4)$ & $43( \pm 5)$ & $23( \pm 4)$ & $50( \pm 4)$ & $52( \pm 4)$ & $32( \pm 5)$ \\
\hline 60 & $33( \pm 5)$ & $33( \pm 3)$ & $12( \pm 4)$ & $33( \pm 5)$ & $32( \pm 3)$ & $14( \pm 3)$ & $40( \pm 4)$ & $40( \pm 4)$ & $18( \pm 3)$ & $45( \pm 4)$ & $43( \pm 4)$ & $18( \pm 4)$ \\
\hline 66 & $31( \pm 3)$ & $31( \pm 3)$ & $9( \pm 3)$ & $33( \pm 4)$ & $30( \pm 3)$ & $14( \pm 4)$ & $35( \pm 3)$ & $36( \pm 3)$ & $13( \pm 4)$ & $40( \pm 5)$ & $42( \pm 4)$ & $21( \pm 3)$ \\
\hline 72 & $28( \pm 4)$ & $28( \pm 3)$ & $9( \pm 2)$ & $30( \pm 3)$ & $22( \pm 3)$ & $11( \pm 2)$ & $32( \pm 3)$ & $33( \pm 3)$ & $10( \pm 4)$ & $35( \pm 3)$ & $36( \pm 4)$ & $17( \pm 3)$ \\
\hline
\end{tabular}

Pixel value for each color at the examined point from 0-255. All examined corneas pixel values showed significant difference with that value at death by LSD. P value $<0.05$

Table (4): Correlation coefficients between postmortem intervals and different parameters.

\begin{tabular}{|c|c|c|c|c|c|c|c|c|c|c|c|c|c|c|c|c|}
\hline & \multicolumn{8}{|c|}{ Winter time } & \multicolumn{8}{|c|}{ Summer time } \\
\hline & \multicolumn{6}{|c|}{ Image analysis } & \multicolumn{2}{|c|}{$\begin{array}{l}\text { Subjective } \\
\text { examination }\end{array}$} & \multicolumn{6}{|c|}{ Image analysis } & \multicolumn{2}{|c|}{$\begin{array}{l}\text { Subjective } \\
\text { examination }\end{array}$} \\
\hline & \multicolumn{3}{|l|}{$\mathrm{C}$} & \multicolumn{3}{|l|}{0} & \multirow[t]{2}{*}{$\mathrm{C}$} & \multirow[t]{2}{*}{0} & \multicolumn{3}{|l|}{$\mathrm{C}$} & \multicolumn{3}{|l|}{0} & \multirow[t]{2}{*}{$C$} & \multirow[t]{2}{*}{0} \\
\hline & $R$ & $\mathrm{G}$ & $B$ & $R$ & $\mathrm{G}$ & $B$ & & & $R$ & G & $B$ & $R$ & G & $B$ & & \\
\hline$r$ & 0.81 & 0.65 & 0.53 & 0.78 & 0.63 & 0.54 & 0.46 & 0.49 & 0.83 & 0.59 & 0.52 & 0.78 & 0.62 & 0.51 & 0.53 & 0.56 \\
\hline$p$ & 0.001 & 0.01 & 0.01 & 0.001 & 0.01 & 0.01 & 0.03 & 0.01 & 0.001 & 0.01 & 0.01 & 0.001 & 0.01 & 0.01 & 0.01 & 0.01 \\
\hline
\end{tabular}

$r$ : correlation coefficient, $p<0.05$ is significant. C: closed eye. O: opened eye. $R, G, B$ stand for red, green and blue color.

Table (5): Equations for the estimation of postmortem intervals by simple regression using image analysis of rabbit corneas in different conditions and temperatures

\begin{tabular}{|c|c|c|c|c|c|}
\hline & & & Equation & $\mathrm{R}^{2}$ & SEE (hr.) \\
\hline \multirow[t]{6}{*}{ Winter } & \multirow[t]{3}{*}{ C } & $\mathrm{R}$ & $11.45-\mathrm{R} \times 0.34$ & .66 & 2.3 \\
\hline & & G & $14.82-\mathrm{G} \times 0.88$ & .42 & 3.3 \\
\hline & & $B$ & $9.65-\mathrm{B} \times 0.76$ & .28 & 3.5 \\
\hline & \multirow[t]{3}{*}{$\mathrm{O}$} & $\mathrm{R}$ & $15.46-\mathrm{R} \times 0.79$ & .61 & 2.5 \\
\hline & & G & $13.88-\mathrm{G} \times 0.88$ & .40 & 3.3 \\
\hline & & B & $10.26-\mathrm{B} \times 0.80$ & .29 & 3.5 \\
\hline \multirow[t]{6}{*}{ Summer } & \multirow[t]{3}{*}{ C } & $\mathrm{R}$ & $11.89-\mathrm{R} \times 0.79$ & .69 & 2.1 \\
\hline & & G & $13.86-\mathrm{G} \times 0.88$ & .35 & 3.4 \\
\hline & & $B$ & $8.29-\mathrm{B} \times 0.81$ & .27 & 3.6 \\
\hline & \multirow[t]{3}{*}{$\mathrm{O}$} & $\mathrm{R}$ & $12.45-\mathrm{R} \times 0.80$ & .61 & 2.5 \\
\hline & & G & $13.82-\mathrm{G} \times 0.32$ & .38 & 3.4 \\
\hline & & $B$ & $9.26-\mathrm{B} \times 0.12$ & .26 & 3.5 \\
\hline
\end{tabular}

Equations for calculation of $\mathrm{PMI}$ in $\mathrm{hr} .=\mathrm{a} X$ pixel value - constant. SEE: standard error of estimate. $R, G$, and $B$ stand for red, green and blue colors. 
Table (6): Equations for the estimation of postmortem intervals by simple regression analysis using subjective examination of rabbit corneal opacity in different conditions and temperatures

\begin{tabular}{|l|l|l|l|l|}
\hline & & Equation & $\mathrm{R}^{2}$ & SEE (hr.) \\
\hline Winter & $\mathrm{C}$ & 2.92 - score X 0.83 & .21 & 7.5 \\
\cline { 2 - 5 } & $\mathrm{O}$ & 2.91 - score X 0.44 & .24 & 7.9 \\
\hline Summer & $\mathrm{C}$ & 3.05 - score X 1.73 & .28 & 6.4 \\
\cline { 2 - 5 } & $\mathrm{O}$ & 3.01 - score X1.51 & .31 & 6.3 \\
\hline
\end{tabular}

Equations for calculation of PMI in $\mathrm{hr} .=\mathrm{a} X$ score value - constant. SEE: standard error of estimate.

Table (7): Equations for the estimation of postmortem intervals by multiple regression using image analysis of rabbit corneas in different conditions and temperatures

\begin{tabular}{|l|l|l|l|l|}
\hline & & Equation & $\mathrm{R}^{2}$ & SEE (hr.) \\
\hline Winter & $\mathrm{C}$ & $14.67-0.072 \mathrm{R}-0.066 \mathrm{G}-0.057 \mathrm{~B}$ & 0.945 & 1.2 \\
& & & & \\
\cline { 2 - 5 } & $\mathrm{O}$ & $16.07-0.013 \mathrm{R}-0.014 \mathrm{G}-0.012 \mathrm{~B}$ & 0.977 & 1.1 \\
\hline \multirow{3}{*}{ Summer } & $\mathrm{C}$ & $12.32-0.021 \mathrm{R}-0.021 \mathrm{G}-0.11 \mathrm{~B}$ & 0.955 & 1.1 \\
& & & & \\
\cline { 2 - 5 } & $\mathrm{O}$ & $13.82-0.022 \mathrm{R}-0.042 \mathrm{G}-0.018 \mathrm{~B}$ & 0.922 & 1.3 \\
\hline
\end{tabular}

Equations for calculation of PMI in hr. = a X pixel value - constant. SEE: standard error of estimate. R, G, and B stand for red, green and blue colors. 

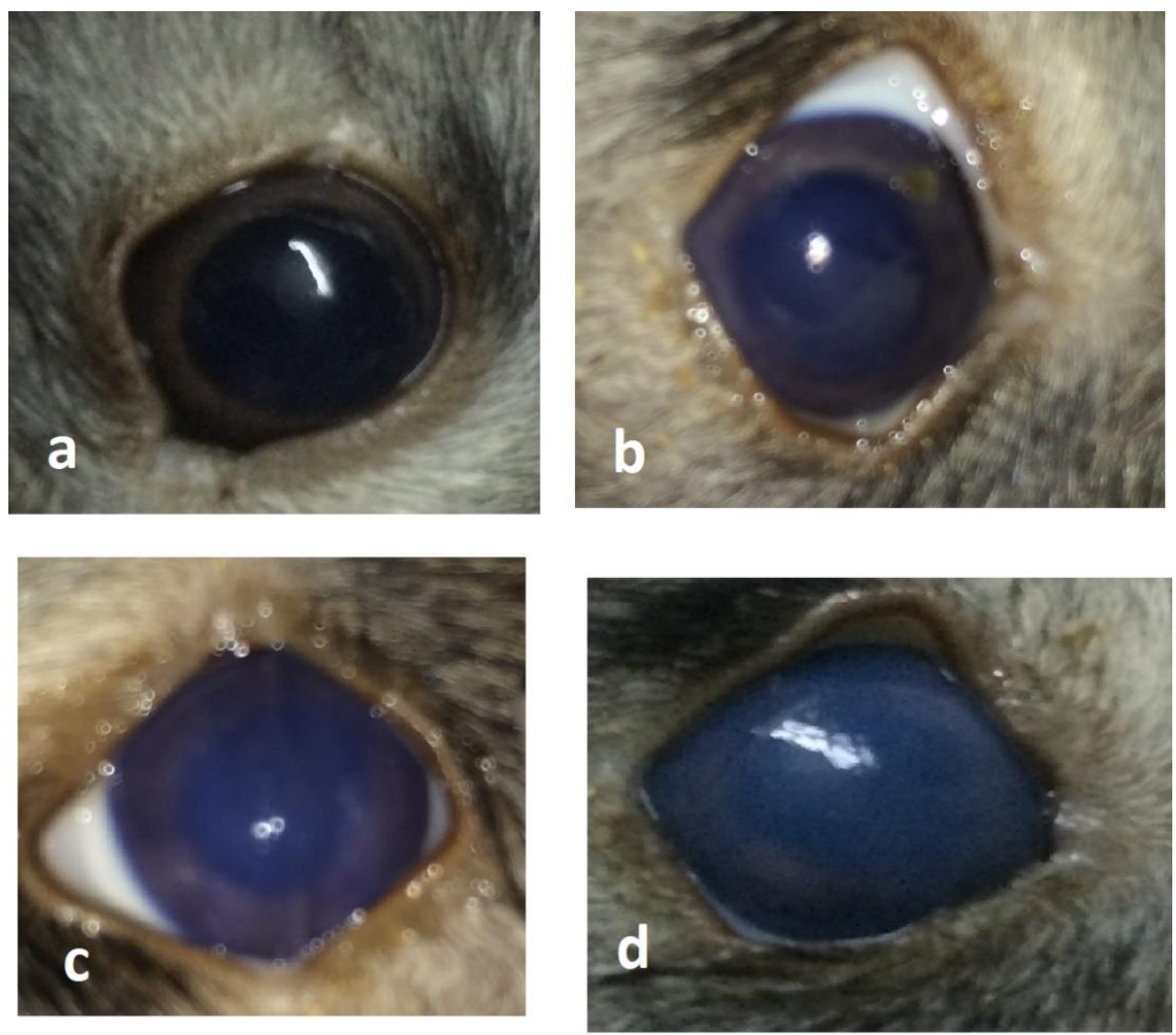

Figure (1): shows different eyes with different degrees of opacities. Figure a, b, c, and d represent cornea with score 1, 2, 3, and 4 respectively (no, slight, moderate and marked opacity).

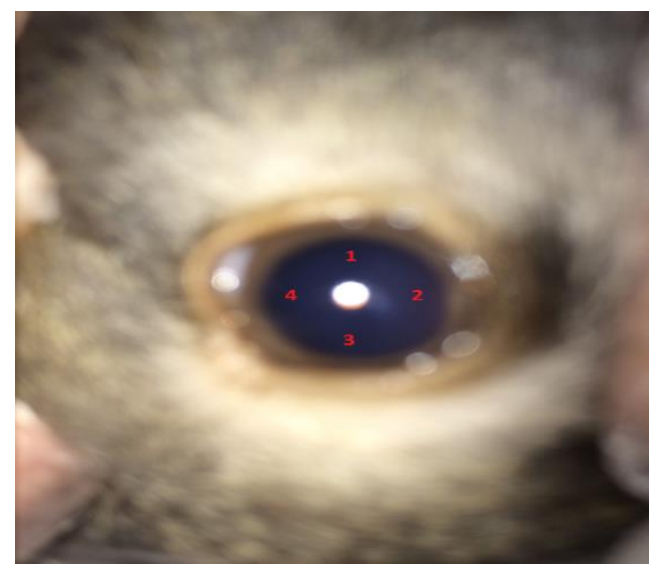

Figure (2): shows the 4 selected points of the cornea examined for pixel values. 


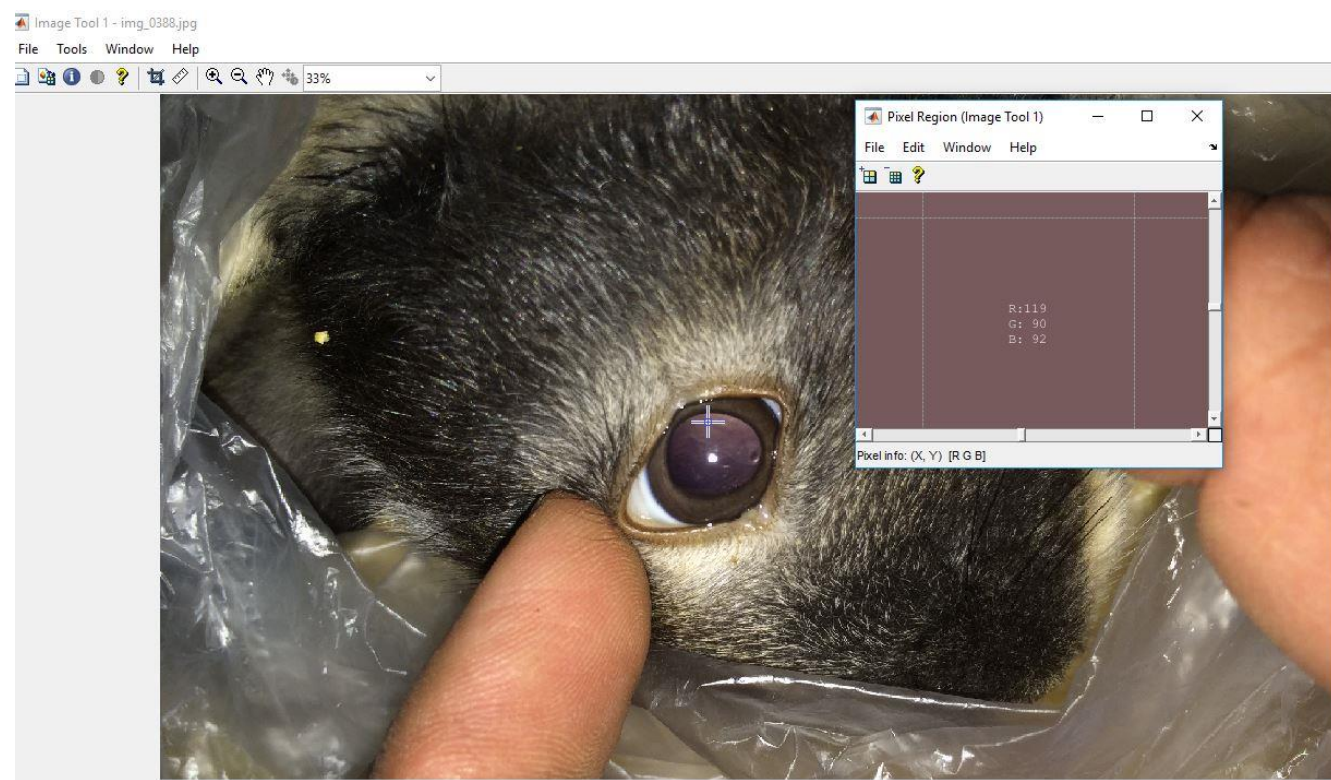

Figure (3): shows a color image of rabbit cornea examined by MATLAB program with red, blue and green pixel values of the selected point of the cornea.

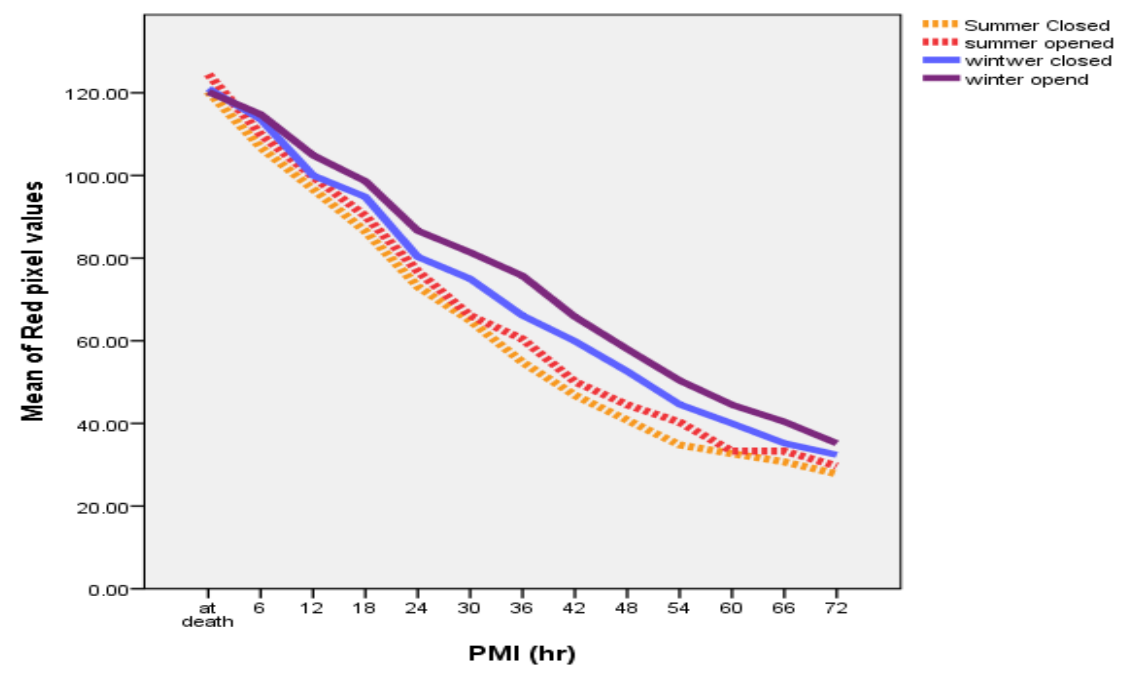

Figure (4): shows the relation between mean of red pixel value of rabbit eyes examined in different postmortem intervals and different conditions.

Summer closed: rabbits eye examined in summer months with closed eye lids. Summer opened: rabbits eye examined in summer months with opened eye lids. Winter closed: rabbits eye examined in winter months while closed eye lids.

Winter opened: rabbits eye examined in winter months while opened eye lids. 


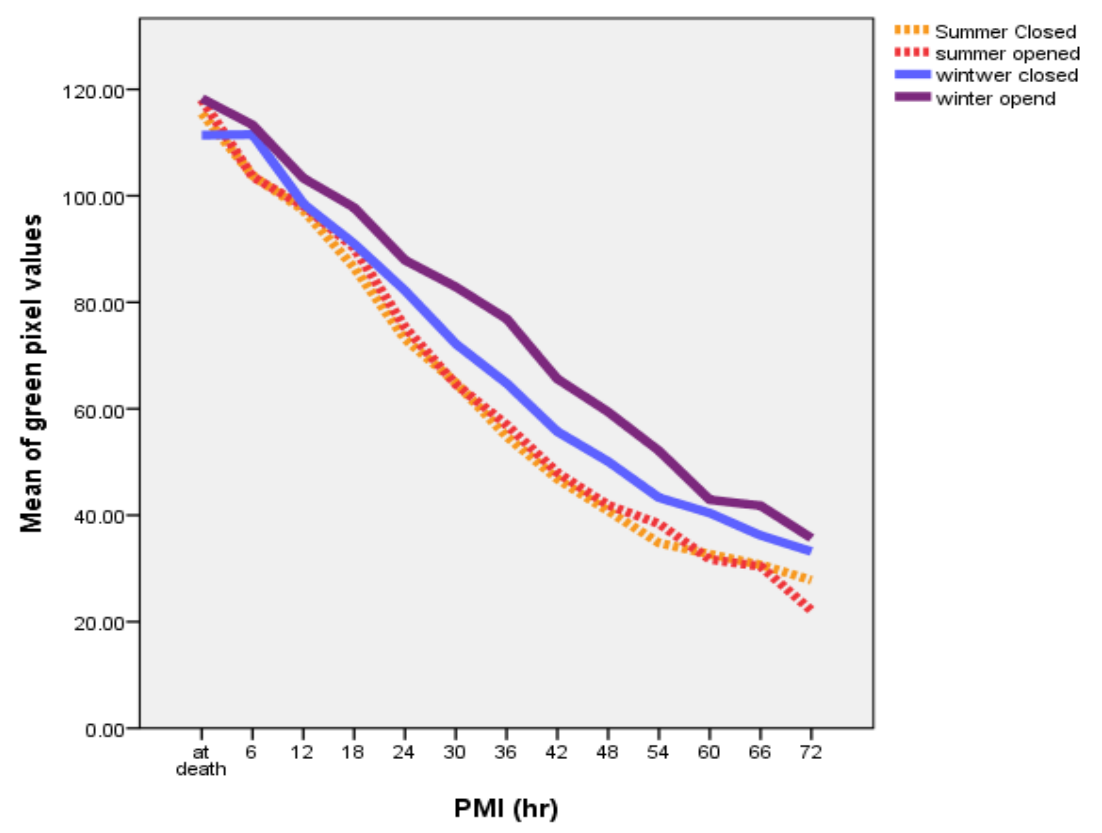

Figure (5): shows the relation between mean of green pixel value of rabbit eyes examined in different postmortem intervals and different conditions.

Summer closed: rabbits eye examined in summer months with closed eye lids. Summer opened: rabbits eye examined in summer months with opened eye lids. Winter closed: rabbits eye examined in winter months while closed eye lids. Winter opened: rabbits eye examined in winter months while opened eye lids.

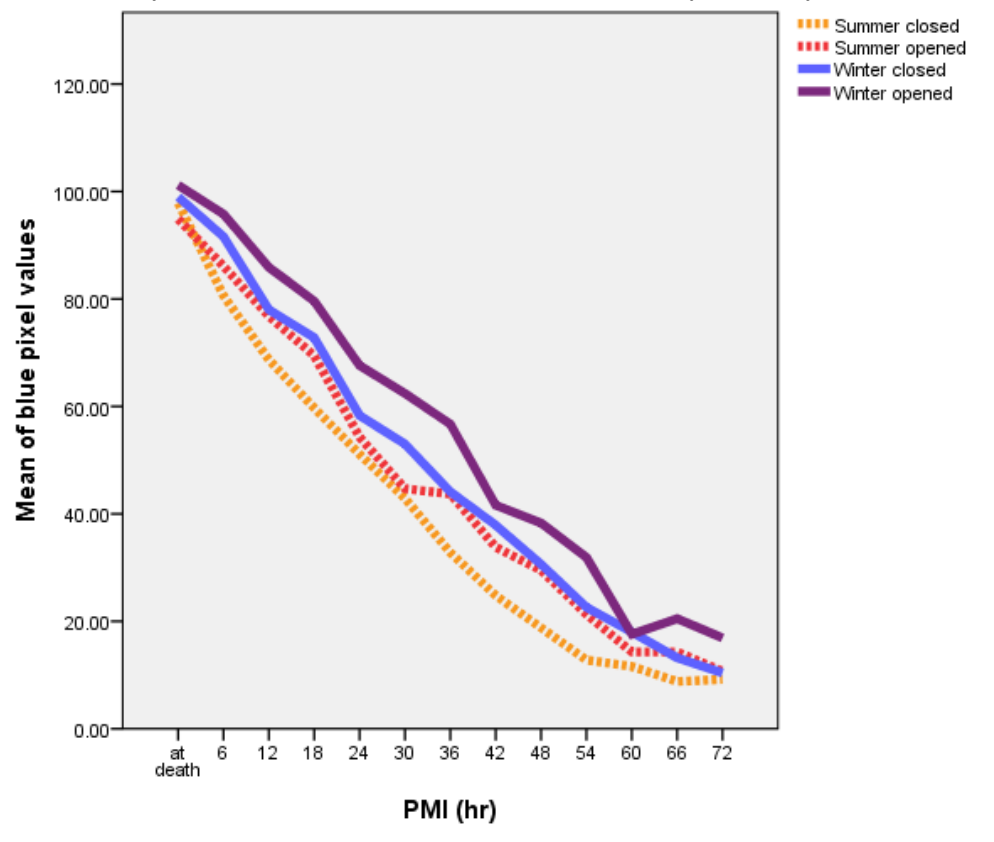

Figure (6): shows the relation between mean of blue pixel value of rabbit eyes examined in different postmortem intervals and different conditions.

Summer closed: rabbits eye examined in summer months with closed eye lids.

Summer opened: rabbits eye examined in summer months with opened eye lids.

Winter closed: rabbits eye examined in winter months while closed eye lids.

Winter opened: rabbits eye examined in winter months while opened eye lids. 


\section{DISCUSSION}

During live, cornea is clear and transparent to reflect light properly. Observation of the eye after death revealed corneal haziness due to hydration changes and affection of lamellar collagen fibers in corneal stroma, degeneration of corneal endothelium. Protein degradation is believed to be increased with temperature (Kawashima et al., 2015).

We have observed postmortem corneal opacity subjectively and found that there is a gradual increase in the corneal opacity over time. By analyzing corneal images with MATLAB, a decrease in all $R$, $G$, and $B$ pixel values over time was observed. Red pixel values give strongest correlation with postmortem interval while subjective assessments give moderate correlation.

These results were in accordance with that of Canturk et al (Cantürk et al., 2017) who studied images of human eyes, they revealed decrease in $\mathrm{RGB}$ values over time. In contrary to our results, Kawashima et al. (Kawashima et al., 2015) reported increase of RGB values with time passed since death. This discrepancy could be attributed to the difference in the examined areas of the corneas. Kawashima et al. (Kawashima et al., 2015) examined the peripheral areas of corneas that affected by iris colors. In this study, authors analyzed central areas of the corneas that are not affected by iris colors.
On using simple regression analysis, prediction of the postmortem intervals using image analysis parameters is better than when subjective assessment was employed. This result appeared from the improved r-values of that RGB pixel values than that of scoring subjective method.

When come to study the effect of eye closure and ambient temperature. There is slight increase in the corneal opacity in the closed eye in comparing with opened one and more in summer than in winter. With closed eyes, the cornea will turn hazy more quickly. According to the authors' knowledge, this the first research described the effect of eye closure in development of corneal opacity. However it was described as a research note by Tsunenari et al, (Tsunenari et al., 1977) without statistical comparing with opened eye. Air exposure and the surrounding humidity may help in delaying corneal cloudiness in opened eyes.

As expected, the ambient temperature has a significant effect upon corneal opacity. The rate of corneal opacity increased markedly in summer time. Corneas became markedly opaque after $60 \mathrm{~h}$ in summer time $72 \mathrm{~h}$ in winter time. These results agree with several authors (Poloz and O'Day, 2009, Xu et al., 1999).

Digital image analysis of the cornea has many advantages as described by Kawashima et al. (Kawashima et al., 2015). The results of image processing are reliable, reproducible, noninvasive, with less human error. Image 
analysis gives numerical scores in opposite to subjective method. Additional superiority of digital image analysis was concluded from this study. Image analysis method could detect minimal changes in the corneal opacity. SEE are much lower in the objective methods in comparing to that of the subjective methods.

Even with the advantages of digital image processing over the subjective approaches for the estimating postmortem interval from corneal opacity examination, multiple factors affect the process of photographing. Lightening, angle, and distance between object and camera are examples of these factors (Häkkinen et al., 2008). These factors are avoided in subjective methods. However, lightening, angle and distance of photographing could be standardized to minimize its effects on image processing procedure.

\section{CONCLUSION}

The results achieved by this study concluded that corneal opacity increase with increased time passed since death. Digital image analysis (especially red pixel value) gives stronger correlation with post mortem interval than that of subjective analysis. There is improvement of SEE from 2.5-3.6 hr. to 1.1-1.3 when using equation of 3 elements of colors (R, G, and B). Corneal opacity slightly increased in closed eye than in opened one. In summer corneal opacity occur faster than in winter.

\section{REFERENCES}

AOKI, T. J. J. M. J. (1965):

Studies on the estimation of time after death. 12, 164-177.

BOWLING, B. (2015): Kanski's Clinical Ophthalmology EBook: A Systematic Approach, Elsevier Health Sciences.

CANTÜRK, İ., ÇELIK, S., ŞAHIN, M. F., YAĞMUR, F., KARA, $\mathbf{S}$ ‘.KARABIBER, $\mathbf{F}$. J. B. \& ENGINEERING, B. (2017): Investigation of opacity development in the human eye for estimation of the postmortem interval. 37, 559565.

CHEN, H., ZHU, S., FANG, D. J. F. S. \& TECHNOL (2007): An study on the relationship between changes of corneal AQP1 and postmortem interval. 2, 15-17.

DUBEY, R. K., GOH, J., THING, V. L. J. I. T. O. I. F. \& SECURITY (2016):

Fingerprint liveness detection from single image using lowlevel features and shape analysis. 11, 1461-1475.

FANG, D., LIANG, Y-.R. \& CHEN, H. J. F. S. T. (2007): The advance on the mechanism of corneal opacity and its application in forensic medicine. 2, 36-8.

FURUKAWA, M., FUNAO, T. \& NAGASAKI, Y. J. K. M. (1985): A new estimation of lapse of time since death by corneal turbidity. 15, 364-367.

HÄKKINEN, J., KAWAI, T., TAKATALO, J., LEISTI, T., RADUN, J., HIRSAHO, A. \& NYMAN, G.( 2008): 
Measuring stereoscopic image quality experience with interpretation based quality methodology. Image Quality and System Performance V, International Society for Optics and Photonics, 68081B.

HENSSGE, C. \& MADEA, B. J. F. S. I. (2004): Estimation of the time since death in the early post-mortem period. 144,167 176.

KAWASHIMA, W., HATAKE, K., KUDO, R., NAKANISHI, M., TAMAKI, S., KASUDA, S., YUUI, K \& .ISHITANI, A. J. J. O. F. R. (2015):

Estimating the time after death on the basis of corneal opacity. 6,1 .

KUMAR, B., KUMARI, V., MAHTO, T., SHARMA, A. \& KUMAR, A. J. J. I. A. F. M. (2012): Determination of time elapsed since death from the status of transparency of cornea in ranchi in different weathers. 34, 336-8.

LIU, C. \& XIONG, P. J. F. Y. X.

Z. Z. (2003): The relationship between the postmortem interval and the changes of DNA content in rabbit's cornea epithelial and endothelium by the computerized image analysis. 19, 76-77.

MENG, Y., WANG, C. \& FU, C. J. M. J. W. U. (2001): An Experimental Pathological Study of the Relationship between the Corneal Thickness and the Time of Death. 22, 3536.

POLOZ, Y. O. \& O'DAY, D. H. J. I. J. O. L. M. (2009):

Determining time of death: temperature-dependent postmortem changes in calcineurin A, MARCKS, CaMKII, and protein phosphatase 2A in mouse. 123, 305-314.

SALAM, H. A., SHAAT, E. A., AZIZ, M. H. A., MONEIMSHETA, A. A. \& HUSSEIN, H. A. S. M. J. A. J. O. M. (2012): Estimation of postmortem interval using thanatochemistry and postmortem changes. 48,335 344.

SONG, G. \& SHI, J. J. F. S. T. (2001): Study of corneal endothelium cell and its application in forensic medicine. 1, 36-7.

TSUNENARI, S., KANDA, M. J. $M$ ‘.SCIENCE \& LAW, T. (1977): The post-mortem changes of corneal turbidity and its water content. 17, 108-111.

TSUNENARI, S., OHO, S., SASAKI, S., MUTO, H., KANDA, M. \& MED, M.-L. S. O. J. J. J. J. L. (1974): The development of the laser apparatus to determine corneal turbidity-model. 28, 281-285.

TSUNENARI, S., WATANABE, S., TAKAHAMA, K. \& KANDA, M. J. N. H. Z. T. J. J. O. L. M. (1971): A method to determine the corneal turbidity by the application of Laser. 1. 25, 373-375.

VINER, M. (2018): Overview of Advances in Forensic Radiological Methods of Human Identification. New Perspectives in Forensic Human Skeletal Identification. Elsevier. 
XU, C., ZHANG, H. \& QIAN, S. J. C. J. F. M. (1999): The influence of temperature on the feature parameter of the endothelial cell living rate from corpse cornea. 14, 33-34.

YANG, W.-C., TSAI, L.-H. \& CHEN, C.-H. J. F. S. J. (2017): Applying the Sensor Noise based Camera Identification Technique to Trace Origin of Digital Images in Forensic Science. 16, 19-42.

ZBIEĆ-PIEKARSKA ‘R., SPÓLNICKA, M., KUPIEC, T., MAKOWSKA, $\dot{Z}$., SPAS, A., PARYS-PROSZEK, A., KUCHARCZYK, K.,
PLOSKI, R. \& BRANICKI, W. J. F. S. I. G. (2015):

Examination of DNA methylation status of the ELOVL2 marker may be useful for human age prediction in forensic science. 14, 161-167.

ZHOU, L., LIU, Y., LIU, L., ZHUO, L., LIANG, M., YANG, F., REN, L., ZHU, S.

J. J. O. H. U. O. S. \& TECHNOLOGY (2010): Image analysis on corneal opacity: a novel method to estimate postmortem interval in rabbits. 30, 235-239. 


\section{الملخص العربي}

التحليل الثخصي مقابل التحليل الرقمي لصور تعتيم القرنية كأداة لتقدير الوقت منذ الوفاة مع

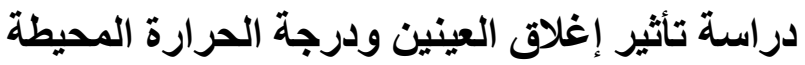

$$
\text { ميلاد جاد بولس *\#" ، رحاب حسني عبد الكريم يونس * }
$$

* قسم الطب الثرعي والسموم، كلية الطب، جامعة المنيا، مصر.

\# ق قسم الباطنة العامة، كلية الطب، جامعة مؤتة، الأردن.

تقدير الوقت منذ الوفاة يعتبر احدي تحديات الطب الشرعي ولذلك توصي الأبحاث العلمية باستخدام وسائل

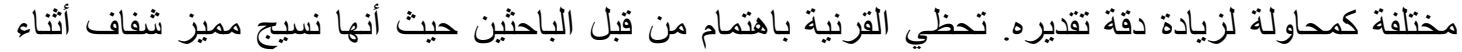

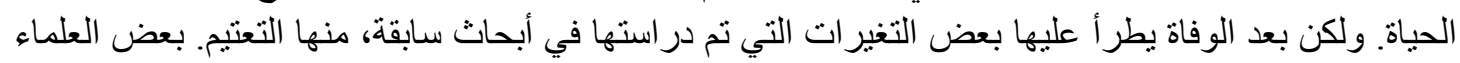

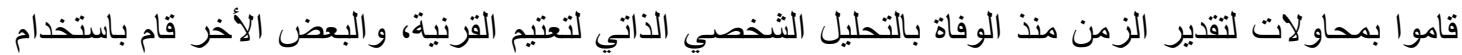
التقنيات الرقمية الحديثة لتحليل تعتيم القرنية ومحاولة إيجاد رابط بينه وبين الوقت منذ الوفاة.

تهدف هذه الدر اسة إلي عقد مقارنة بين الطريقة الثخصية والطريقة الرقمية في تحليل تعتيم القرنية. بالإضافة

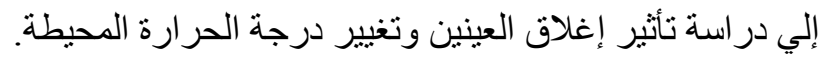

أجريت هذه الدراسة علي الأرانب بكلية الطب، جامعة المنيا. تم تصوير العين بعد الوفاة علي فترات زمنية

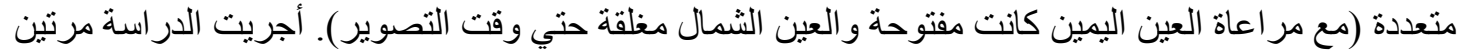

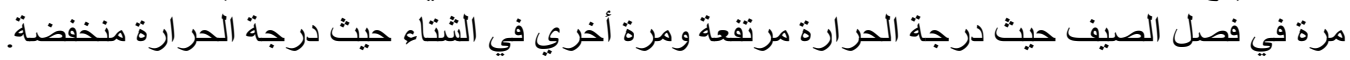
اعتمد التحليل الثخصي علي نظام النقاط بينما التحليل الرقمي اعتمد علي برنامج كمبيونر لقياس قيمة أصغر

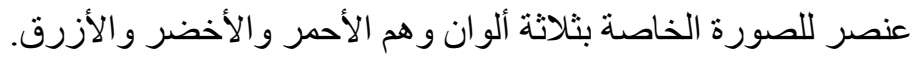

خلصت الدراسة إلي أن تعتيم القرنية يزداد مع زيادة الوقت المنقضي بعد الوفاة ويحدث أسرع عند قفل العينين وفي فصل الصيف أكثر من الثنتاء.

و عند مقارنة الطريقة الثخصية بالطريقة الرقية أثبتت الدراسة أن اتباع الطريقة الرقمية لتحليل تعتيم القرنية

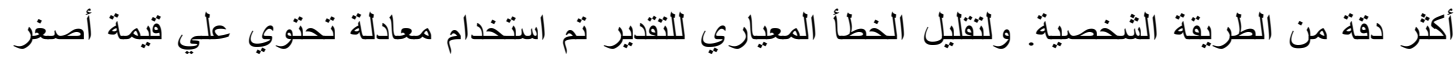

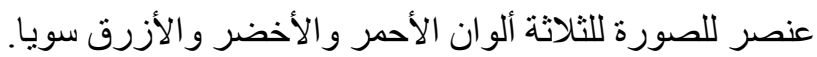

